\title{
THE USE OF VIDEOCONFERENCE FOR SPEAKING CLASS IN MAHASARASWATI DENPASAR UNIVERSITY: PRACTICE AND PERCEPTION
}

\author{
N.P.S. Widiastuti ${ }^{1}$, N.N. Padmadewi ${ }^{2}$, N.L.P.E.S. Dewi ${ }^{3}$ \\ ${ }^{123}$ English Language Education, Universitas Pendidikan Ganesha, Singaraja \\ e-mail: shantyw07@gmail.com , nym.padmadewi@undiksha.ac.id , sulistia.dewi@undiksha.ac.id
}

The objectives of the research was to investigate and analyze the implementation of videoconference as a method to teach speaking; and to analyze teachers' and students' opinion about videoconference. The present research applied a mixed methods research design. The research subjects were 93 students and 2 speaking lecturers. The findings showed that the implementation of videoconference for speaking was seamlessly done. In the pre-activities, lecturer greeted students, sent link of meeting and attendance list, and did apperception. Main activities were done through various teaching methods and strategies for videoconference, namely focus trios, chain speaking and discussion. In the post-activities the students did online game, summarized the lesson, and did the project. The implementation of videoconference mostly utilized Zoom Meeting and others supporting systems, such as: WhatsApp Group, Quizizz, and many more. Lastly, the results of the questionnaire showed positive response as the participants mostly perceive the advantages rather than disadvantages of videoconference provided.

\section{Keywords: Videoconference; Speaking; University Students}

\section{INTRODUCTION}

English is one of essential courses which has been considered for all generation. One of significant goals in learning English is to communicate using the language itself. Speaking is a productive skill where language is actively produced to speak (Baker, 2003). In English language learning, students are educated how to speak appropriately to provide them with the communicative competence. The success of speaking English is when the students can perform the language task assigned and comprehend the speaking competence.

An English speaking lecturer, on the other hand, has a responsibility to teach the students how to communicate in English. Both speaking lecturer and students should be collaboratively engaged in the process of teaching and learning in accordance to the latest trend in foreign language instructions. However, the issue of COVID-19 have recently affected the sustainability of human life in which educational system in Indonesia is no exception. According to Surat Edaran Nomor 4 Tahun 2020 which was released on March 24, 2020 along with the emergency situation of Corona Virus Disease (COVID-19), several policies were implemented to adjust the process of teaching and learning in the pandemic situation. As the impacts of the virus, offline learning would be harmful for students as well as teachers and staffs. A transition of learning style from offline learning to online learning is required.

Conducting an online learning is one of crucial considerations taken to overcome issues of coronavirus as this kind of learning has been developed as an alternative to face-toface meeting while offline meeting still exists (Altiner, 2015; Permatasari, 2018). Online learning is a structured learning activity which provides access to learning experiences by utilizing partially or entirely the use of some technology and internet for instruction, research, assessment, and communication (Means et al., 2010). The use of online learning provides opportunities for learners to experience simplicity in terms of accessibility, connectivity, flexibility and ability to promote varied interactions in educational field (Oblinger \& Oblinger, 2005).

In addition, the use of videoconference is an alternative for online interaction as it provides speaking practice for groups of students and facilitates engagement among them to communicate, negotiate, and interact (Lin, 2007; Vurdien, 2019). Some researchers have 
studied the use of videoconference from different perspectives using a variety of research designs in an educational context (Satar, 2013). The investigations on the design of videoconferencing activities in the language classroom have been conducted (Hampel \& Stickler, 2012). The researchers have further explored the impact of videoconferencing concerning on the enhancement of students' competence (Yang \& Chen, 2014), motivation and self-confidence (Jauregi, et al., 2012), and language learning (Satar, 2013).

Requirement to conduct an online learning influence the researcher to conduct the present research along with the use of videoconference for English students in Mahasaraswati Denpasar University as it is considered urgent based on three crucial considerations. First, conducting a videoconference was a challenging experience for both the teacher and the students as it was rarely done. Second, exploring the design of videoconference activities was a factor affecting the students' opinions of conducting a videoconference. Third, the teachers' and students' opinions on the use of videoconference give insights to conduct videoconference activities in English speaking class. Therefore, the present research was conducted to investigate and analyze the implementation of videoconference as a method to teach speaking for university students and to analyze the teachers' and students' opinion on the use of videoconference.

\section{RESEARCH METHOD}

A mixed quantittive-qualitative method was used as research design. The research was done in Mahasaraswati Denpasar University. The subject of the research was the second year students in which there we there 93 students and 2 teachers who involved in Speaking for Formal Interactions course using videoconference. Meanwhile, the object of the research involved a) the implementation of videoconference and b) the teachers' and the students' opinion on the use of videoconference for English speaking class.

In order to collect the data, there were several methods used in the present research, such as observation, interview, and questionnaire. Meanwhile, research instruments were in form of human instrument, observation sheet, questionnaire, and interview guide. The collected data were analyzed using a method from Miles and Hubberman (1991). In addition, the present research implemented methodological triangulation referring to the use of more than one method for gathering data involving observation, interview, and questionnaire.

\section{FINDINGS AND DISCUSSION}

The classes of Speaking for Formal Interaction course was conducted for 150 minutes once a week in which the meeting should achieve 16 meetings maximum including mid-term and final tasks. During the outbreak of COVID-19, teaching and learning process were done online in the same schedule as in offline class to adjust the arrangement of academic calendar. There were three main stages of learning activities that were observed in the implementation of videoconference, such as introduction, main activities, and post activities. To begin online learning activities, the teacher greeted the students friendly, sent the meeting link, reminded them to fulfill the attendance link by sharing the links via WhatsApp group, and began apperception. The activitiy of apperception was done by displaying pictures related to the lesson and the students were asked several questions related to the pictures. The teacher emphasized that learning instructions were a crucial point that supported the success of teaching speaking via videoconference, as there was distance barrier between the teacher and students to interact freely.

During main activities, the teacher concentrated all of speaking activities to manage efficient time for the students to practice speaking. The process of teaching and learning via videoconference applies, combines and varies teaching methods and strategies. Focus Trios was one of strategies used in order to provide opportunities for the students to be active during the activities while putting the teacher as "guide on the other side". During the implementation of focus trios via videoconference, the students were randomly put into several breakout rooms in Zoom Meeting. The teacher can specifically concern on every group by joining each room of the groups alternately. This private room of discussion gave opportunities for passive students to be more confident in sharing their opinion in a small environment. In the end of the discussion session, the students were back to the general 
meeting room and a representative of each group, furthermore, would share the results of the discussion. Chain speaking, on the other hand, was a method used within groups where every group had to continue a story from previous group like a circle in order to make an authentic narrative story. The teacher provided an orientation to start the story circle where a representative of the first group would continue the story by stating a problem for the next group. The next group would give a solution from the problem given and make a new problem for the next group. Every group was given chance to discuss about the story through WhatsApp Group. During the activities via videoconference, the teacher was able to put attention more on the students' pronunciation, grammar, eye contact, and gesture rather than in offline classroom. Reflecting to the activities, the teacher had considered the proportion of delivering the lesson to maintain student-centered learning environment for the students although it was done online. In addition, the learning activities also concerned on the students' speaking practice to recognize their weaknesses in speaking rather than emphasized on the product of speaking itself.

In the end of learning activities, the teacher utilized online game as a quiz to confirm the students' understanding towards the material given in that day. Quizizz and Kahoot were online games used to create a simple and fun quiz for the students in forms of multiple choice, open-ended questions, and many more. Besides providing a quiz, the teacher also gave projects for the students in order to make them learn more about the lesson given via videoconference. Mostly, the projects were to create a video to help the students practice doing eye contact, gesture, correct pronunciation and grammar in speaking. Since the teachers could not manage all of the students' performance in a time, the projects were really helpful for the teachers to put attention on the students' ability of speaking in which others students were also able to give feedbacks to their friends' speaking performance.

Reflecting to the process of teaching speaking via videoconference, most of learning speaking activities utilized Zoom Meeting as supporting system. There were also others additional systems used in the implementation of videoconference, such as WhatsApp Group, Quizizz, Google Form, Google Drive, and so on. In addition, the use of Zoom Meeting for teaching speaking can facilitate the students to present their speaking performance while the teacher was able to put attention more on the students' pronunciation, grammar, eye contact, and gesture rather than in offline classroom.

Besides the implementation of videoconference for the speaking, the teachers' and the students' opinions on the implementation of videoconference in Speaking for Formal Interactions were also analyzed. There were four dimensions used to categorize the 15 statements of the questionnaire, such as effectiveness of videoconference, ease of access, technology and cost. The results of the questionnaire can be seen in the following picture.

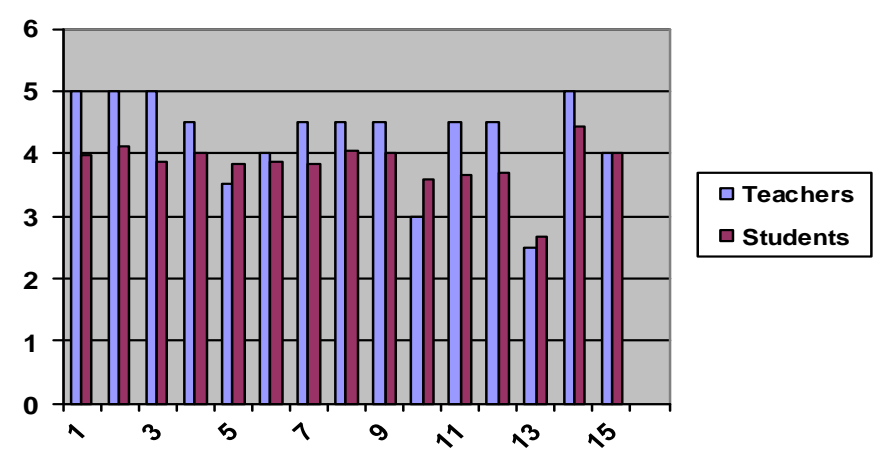

Picture 1. The Results of Teachers' and Students' Questionnaire

Based on Picture 1 above, the results from the teachers' and the students' questionnaire showed positive responses. The teachers' and the students agreed that the use of videoconference was effective for speaking in term of enhancing accessibility, focus, productivity, speaking ability, self-confident, comfort, and autonomous learning. The use of 
videoconference also facilitate interactions among the students or between the teacher and the students to speak, discuss, and share opinion about certain topics. They also agreed about several statements regarding videoconference technology, such as the adequate quality of video and audio as well as the features of screen sharing, audio recording, and so on. However, both the teachers and the students showed disagreement on the statement about obstacles caused by background noise. Lastly, both of them agreed that the use of videoconference can save travel cost. In short, speaking teachers and students mostly experience advantages rather than disadvantages of videoconference.

Reflecting to the findings above, the teachers showed a picture through screen sharing feature in the beginning of the meeting. This involves the process of apperception. Picture introduces a new teaching material, brings the world into the classroom, attract the students' attention, stimulate the students' responses, and provides information which can be referred to conversation, discussion, and storytelling. Frindt (2007) adds that a variety of presentation technique is essential to enhance the students' participation within classroom activities using videoconference, for instance, the use of visual material and graphics. Additionally, teacher can present various abstract concepts with animations and graphics to enhance students' imagination. Fortunately, most videoconference applications can facilitate and transmit various kinds of presentation including pictures, videos, animations, files, and diagrams through its feature of screen sharing.

Speaking teachers has considered, combined and modified various methods or strategies and additional supporting systems for teaching speaking via videoconference to build more interactions among the students or between the teacher and the students. According to Schiller and Mitchell (1993), modifications of teaching strategies, methods, or techniques are necessary for teaching practice using videoconference; thus, "focus is on interaction" (p.51). In relation to the statement, Loranc-Paszylk (2015) argues that the use of videoconference for speaking practice can expose the students to genuine interaction to enhance their communicative experiences. Thus, the implementation of videoconference, along with the use of various methods and strategies, can contribute to the process of online teaching and learning for speaking.

Most activities of videoconference for speaking emphasize on giving students opportunities as much as possible to share and discuss certain topics between speaking teacher and students or among the students. Discussion can develop the students' critical understanding, self-awareness, appreciation for diverse perspectives, and the ability to take action and problem solving (Pawlak \& Waniek-Klimczak, 2014). Chain drill method is suitable for teaching speaking as students alternately ask and answer question about a specific topic of discussion one by one through a chain of conversation. Reflecting to the implementation in Speaking for Formal Interaction course, speaking teacher modified several aspects of the method. The students were grouped and every representative of each group shared a continuous narrative story which consisted of a solution from previous group and a new conflict for next group. Through controlled communication among the students, they are given opportunity to practice their speaking and listening ability, as well as improve their selfconfident in speaking.

Focus trio strategy, furthermore, has been also conducted during the implementation of videoconference for speaking. Jolliffe (2007) explain that the strategy divides students into groups of 3 (trio) to discuss what they have known and what they want to find out on a certain topic. In contrary to the statement, speaking teacher modified students' group division by dividing the students into groups of 4 students. The teacher considered to limit the number of groups to put attention more in every group and manage the time effectively since there were a large number of students in an online class. On the other side, the strategy can enhance the students' respect and understanding on others' abilities, interests and needs; can promote self-confident, risk taking and team building; and can improve responsibility and social skills (Jolliffe, 2007).

Reflecting to the use of methods and strategies above, speaking teachers have organized the students into groups during main activities. Grouping the students during learning activities can help the teachers organize online classroom situation and give opportunities for passive students to confidently speak their ideas within the group. Related 
to these statements, Sun et al. (2018) mention that grouping can control the formation of internal communities when students are randomly grouped, can connect them closely in the same group, can enhance the students' self-reflection during the process, can improve their enthusiasm to participate in the classroom activities, and can help teacher provide equal attentions to the students. In addition, the use of videoconference can facilitate private group discussion for the students through the feature of breakout room. In short, the use of videoconference does not limit online classroom management.

The implementation of videoconference for speaking, along with the use of methods and strategies, shows how teacher manage the proportion of delivering material for the students. The teachers have considered the implementation of student-centered learning although the process of teaching and learning was conducted through videoconference. This is in accordance with Frindt (2007) who suggests that a lecture strategy should be seriously taken into account to avoid the teachers as the only 'talking head' in the online classroom activities via videoconference. Furthermore, various questions should be asked frequently to challenge the students and to check their understanding. The results of the teachers' interview and the researcher's observation have shown that most activities have emphasized on giving the students opportunity to express their ideas and give feedback on their friends' performance.

Looking at speaking learning activities through videoconference in post activities, online games were given as a quiz through Kahoot or Quizizz to check students' understanding on the lesson. Huang and $\mathrm{Hu}$ (2016) explain that educational games are designed for teaching purposes to "expand concept, reinforce development, and assist students in learning a skill as they play" (p.87). In addition, the use of games can stimulate the students' inner motivation, enhance their interest to the classroom activities, and encourage shyer students to take part. Thus, the use of online games for teaching speaking shows that various activities are applicable for the use of videoconference.

The use of supporting systems for videoconference, such as Zoom meeting, Google Meet, WhatsApp group, Kahoot, and Quizizz, had facilitated the teachers and the students to easily communicate. Elfaki et al. (2019) have mentioned that technology is a tool to remove geographical barriers and provide anytime- and anywhere-learning. Zoom meeting is the most frequently used application in Speaking for Formal Interactions in which it is in line with a survey of pocket-lint.com which reported that Zoom Meeting has become one of the leading videoconferencing software apps in 2020.

The results of questionnaire demonstrate positive response from the teachers and the students about their opinions on the use of videoconference for speaking. There are four dimensions highlight on their opinion, such as the effectiveness of videoconference, ease of interaction, videoconference technology, and cost. The effectiveness of videoconference can be seen from comfortable interactions between the teacher and the students within a virtual classroom. The students felt more relaxed, confident, tolerant, appreciative, and motivated during videoconference activities. These statements are in accordance with studies conducted by Alshahrani (2016), Altiner (2015), and Permatasari (2018). Furthermore, the use of videoconference can improve the students' speaking skill. Related to the statement, there are several studies which have evidenced the contribution of videoconference as a means of enhancing students' speaking skills, such as Kim and Craig (2012), and Lee (2007). These studies contrast the study of Dogget (2008) showing no significant difference towards students' achievement between videoconference and face-to-face meeting.

In addition, the results of the questionnaire also shows that the use of videoconference can facilitate interactions among the students or between the teacher and the students. Videoconference has given opportunity to collaborate the students with their fellow friends in producing knowledge. In relation to the statement, videoconference facilitates the users with instantaneous and authentic interaction as well as real-voice conversation where they are able to synchronously communicate with their peers in real time (lino \& Yabuta, 2015). Therefore, the students can do eye contact, gestures and turn-taking during videoconference (Jauregui et al., 2012).

Videoconference has facilitated the users with its sophisticated features. Through the features of meeting recording and screen sharing, videoconference encourages the students 
to learn independently during lesson (Altiner, 2015; Dogget, 2008). During the implementation, the teacher also utilizes the feature of breakout room to group the students during discussion session. Both the teachers and the students agree that the use of videoconference requires stable internet connection as the availability of signal can influence the quality of video and audio. The statement relates to the study of Altiner (2015) and Dogget (2008) explaining that videoconference requires good network connections and large video displays. The students have experienced several technical issues including unstable internet connections, unclear sounds, video delay, and frozen images. The same experiences have been reported in studies from Permatasari, (2018), and Vurdien (2019). Meanwhile, the results of questionnaire also show that the students did not experience any obstacles on interactions and background noises. In contrary with the statement, Permatasari (2018) explains that the obstacles of videoconference are in the limitation of interactions and background noises.

The last questionnaire results show that the use of videoconference can reduce travel cost. The statement relates to the studies of Martin (2005) as well as Schiller and Mitchell (1993) in which videoconference can reduce time and costs to be in a certain location, increase productivity of the learners, and enhance learning access.

As the results, the implementation of videoconference for the third-semester students of Mahasaraswati Denpasar University in Speaking for Formal Interactions course have run seamlessly without any significant problems. The implementation is supported by the use of various methods, strategies, activities and additional supporting system such as Zoom Meeting, WhatsApp Group, Quizizz, and many more. In addition, speaking teachers and students mostly experience advantages rather than disadvantages of videoconference including effectiveness of videoconference, ease of interaction, videoconference technology, and cost.

\section{CONCLUSION AND SUGGESTIONS}

The implementation of videoconference in Speaking for Formal Interactions course was seamlessly done during the outbreak of COVID-19. In introduction activities, the teacher greeted the students friendly, sent the meeting link, reminded them to fulfill online attendance list, and apperception by sharing pictures. Main activities were conducted by applying, combining and varying teaching methods and strategies for videoconference, such as focus trios, chain speaking and discussion. These methods and strategies emphasized on studentcentered learning where the students were given opportunities to actively share their ideas, discuss certain related topics, and give feedbacks to their friends' performance. In the end of the meeting, the students were asked to do a quiz through an online game, summarize the lesson, and do a project. The implementation of videoconference mostly utilized Zoom Meeting by combining several additional systems such as WhatsApp Group, Quizizz, Kahoot, YouTube, Google Drive and Google Form. Therefore, the process of teaching and learning through videoconference in Speaking for Formal Interactions course ran effectively during the outbreak of COVID-19. Both the results from the teachers' and the students' questionnaire showed positive response as speaking teachers and students mostly experience advantages rather than disadvantages of videoconference.

Since the implementation of videoconference for speaking is well-accepted by speaking teachers as well as students, the use of videoconference can be considered to be used for others related speaking course in Mahasaraswati Denpasar University, for instance, Speaking for Academic Purposes course and Speaking for Informal Interactions. Although the implementation of videoconference has conducted various methods and strategies as well as a variety of additional supporting systems, there are still others variety of methods, strategies, and supporting systems that should be further investigated and analyzed in order to present various comprehensive references for speaking teachers. Therefore, others researchers are expected to further research on those problems.

\section{REFERENCES}

Alshahrani, A. (2016). Communicating authentically: Enhancing EFL students' spoken English via videoconferencing. CALL-EJ, 17(2), 1-17. 
Altıner, C. (2015). Perceptions of undergraduate students about synchronous video conference-based english courses. Procedia - Social and Behavioral Sciences, 199, 627-633. doi:10.1016/j.sbspro.2015.07.589.

Baker, J. (2003). Essential Speaking Skill: a Handbook for English Language Teachers. New York: Continuum.

Elfaki, N. K., Abdulraheem, I., \& Abdulrahim, R. (2019). Impact of e-learning vs traditional learning on student's performance and attitude. International Journal of Medical Research \& Health Sciences, 8(10), 76-82.

Frindt, T. (2007). The impact of video conferencing on distance education courses: A university of Namibia case study. Progressio, 29(1 \& 2), 56-68.

Hampel, R. \& Stickler, U. (2012). The use of videoconferencing to support multimodal interaction in an online language classroom. ReCALL, 24 (2), 116-137.

Huang, X., \& Hu, X. (2016). Teachers' and Students' Perceptions of Classroom Activities Commonly Used in English Speaking Classes. Higher Education Studies, 6(1), 87-100.

lino, A., \& Yabuta, Y. (2015). The effects of video SCMC on English proficiency, speaking performance and willingness to communicate. In F. Helm, L. Bradley, M. Guarda, \& S. Thouësny (Eds), Critical CALL - Proceedings of the 2015 EUROCALL Conference, Padova, Italy (pp. 254-260). Dublin: Research-publishing. net. http://dx.doi.org/10.14705/rpnet.2015 .000342.

Jauregi, K., de Graaff, R., van den Bergh, H. \& Kriz, M. (2012). Native/nonnative speaker interactions through video-web communication: A clue for enhancing motivation? Computer Assisted Language Learning, 25(1), 1-19.

Jolliffe, W. (2007). Cooperative learning in the classroom: Putting it into practice. London: Sage Publication Inc.

Kim, J. and Craig, D. (2012). Validation of a videoconferenced speaking test. Computer Assisted Language Learning, 25, 257.

Loranc-Paszylk, B. (2015). Videoconferencing as a tool for developing speaking skills. In Issues in teaching, learning and testing speaking in a second language (pp. 189-203). Springer.

Martin, M. (2005). Seeing is believing: The role of videoconferencing in distance learning. British Journal of Educational Technology, 36 (3), 397-405.

Means, B., Toyama, Y., Murphy, R., Bakia, M. \& Jones, K. (2010). Evaluation of evidencebased practices in online learning: A meta-analysis and review of online-learning studies. Washington, DC: U.S. Department of Education.

Oblinger, D. G., \& Oblinger, J. L. (2005). Educating the net generation. EDUCAUSE.

Pawlak, M., \& Waniek-Klimczak, E. (Eds.). (2014). Issues in teaching, learning and testing speaking in a second language. NY: Springer.

Permatasari, Y. B. (2018). Male and female students' perceptions toward the implementation of video conference as a distance learning media that enhances teachers' productivities. JALL: Journal of Applied Linguistics and Litercy, 2(2), 101-112.

Satar, M. (2013). Multimodal language learner interactions via desktop videoconferencing within a framework of social presence: Gaze. ReCALL, 25(1), 122-142.

Schiller, J., \& Mitchell, J. (1993). Interacting at a distance: Staff and student perceptions of teaching and learning via video conferencing. Australian Journal of Educational Technology, 9(1), 41-58.

Sun, B., Wang, M., \& Guo, W. (2018). The Influence of Grouping/Non-grouping Strategies Upon Student Interaction in Online Forum: A Social Network Analysis. 2018 International Symposium on Educational Technology (ISET). 
doi:10.1109/iset.2018.00046.

Vurdien, R. (2019). Videoconferencing: Developing students' communicative competence. Journal of Foreign Language Education and Technology, 4(2), 269-298.

Yang, S. C., \& Chen, J. J. (2014). Fostering foreign language learning through technology enhanced intercultural projects. Language Learning \& Technology, 18(1), 57-75. 